\title{
Alpha-synuclein and tau: teammates in neurodegeneration?
}

\author{
Simon Moussaud ${ }^{1}$, Daryl R Jones ${ }^{1}$, Elisabeth L Moussaud-Lamodière ${ }^{1}$, Marion Delenclos ${ }^{1}$, Owen A Ross ${ }^{1,2}$ \\ and Pamela J McLean ${ }^{1,2^{*}}$
}

\begin{abstract}
The accumulation of a-synuclein aggregates is the hallmark of Parkinson's disease, and more generally of synucleinopathies. The accumulation of tau aggregates however is classically found in the brains of patients with dementia, and this type of neuropathological feature specifically defines the tauopathies. Nevertheless, in numerous cases a-synuclein positive inclusions are also described in tauopathies and vice versa, suggesting a co-existence or crosstalk of these proteinopathies. Interestingly, a-synuclein and tau share striking common characteristics suggesting that they may work in concord. Tau and a-synuclein are both partially unfolded proteins that can form toxic oligomers and abnormal intracellular aggregates under pathological conditions. Furthermore, mutations in either are responsible for severe dominant familial neurodegeneration. Moreover, tau and a-synuclein appear to promote the fibrillization and solubility of each other in vitro and in vivo. This suggests that interactions between tau and a-synuclein form a deleterious feed-forward loop essential for the development and spreading of neurodegeneration. Here, we review the recent literature with respect to elucidating the possible links between a-synuclein and tau.
\end{abstract}

Keywords: Tau, MAPT, Synuclein, SNCA, Oligomers, Tangles, Synucleinopathy, Tauopathy, Parkinson's disease, Alzheimer's disease

\section{Introduction}

Age-related neurodegenerative disorders like Alzheimer's disease (AD) and Parkinson's disease (PD) take an overwhelming toll on individuals and society [1]. AD and PD are the two most frequent neurodegenerative diseases (www.who.org). To date, PD and AD remain incurable and only very limited palliative treatment options exist [2]. The etiology of PD and AD is not fully understood, but appears to involve a complex combination of environmental and genetic factors [3].

Interestingly, at the molecular level, protein misfolding, accumulation, aggregation and subsequently the formation of amyloid deposits are common features in many neurological disorders including AD and PD. Thus neurodegenerative diseases are sometimes referred to as proteinopathies [4]. The existence of a common mechanism suggests that neurodegenerative disorders likely share a

\footnotetext{
* Correspondence: McLean.Pamela@mayo.edu

'Mayo Clinic Jacksonville, 4500 San Pablo Road, Jacksonville, FL 32224, USA

${ }^{2}$ Mayo Graduate School, Mayo Clinic College of Medicine, 2001 st St SW,
} Rochester, MN 55905, USA common trigger and that the nature of the pathology is determined by the type of the aggregated protein and the localization of the cell affected (Figures 1, 2 and 3).

$\mathrm{PD}$ is pathologically characterized by the presence of Lewy bodies in the subcortical regions of the brain, which are composed of aggregated and phosphorylated alphasynuclein protein ( $\alpha$ syn) (Figures 2 and 3) [5]. Hence PD belongs to a cluster of neurodegenerative disorders called synucleinopathies, which also includes Parkinson's disease with dementia (PDD), dementia with Lewy bodies (DLB) and multiple system atrophy (MSA) [6,7] (Figure 1). AD can be classified as a tauopathy (as well as an amyloidopathy); a class of disorders with intracellular inclusions composed of hyperphosphorylated and aggregated tau protein in the form of neurofibrillary tangles or Pick's bodies (Figures 2 and 3) [8]. Tauopathies also include frontotemporal dementia with parkinsonism linked to tau mutations on chromosome 17 (FTDP-17 T), Pick's disease (PiD), progressive supranuclear palsy (PSP) and corticobasal degeneration (CBD) (Figure 1). 


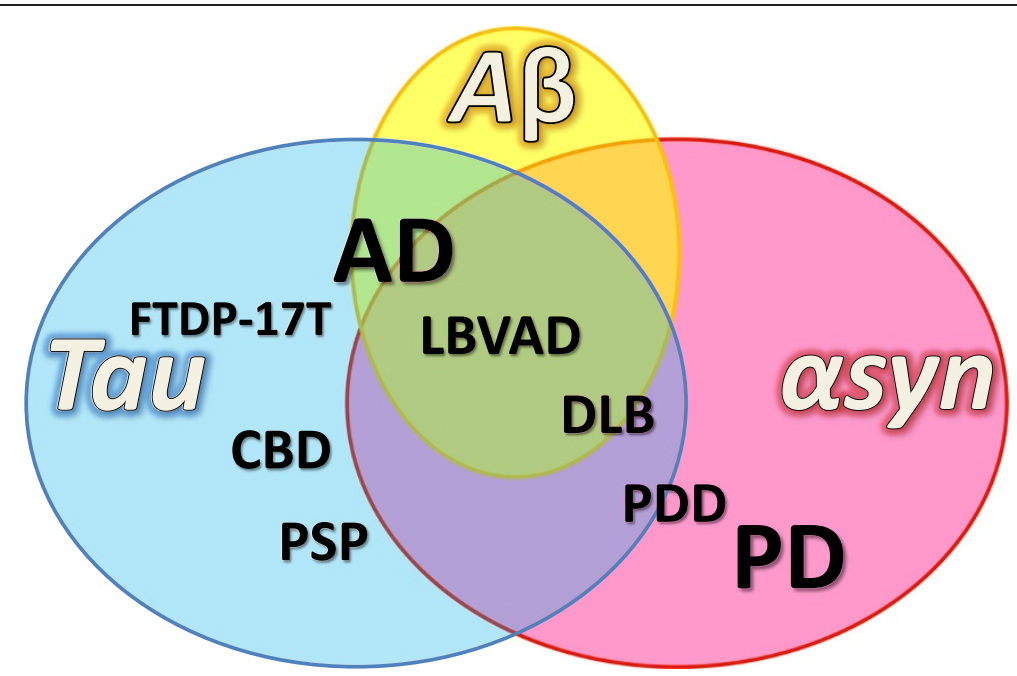

Figure 1 Overlap of proteinopathies. In numerous neurodegenerative disorders, amyloid deposits composed of a-synuclein protein (red circle), tau protein (blue circle) and A $\beta$ peptide (yellow circle) are found. Histopathological classification of neurodegenerative diseases is based on the nature and localization of these deposits in the nervous system. The pathologies are not hermetically isolated categories but form a continuum and concomitance of asyn and tau pathology is not rare. aSyn pathology (or synucleinopathy) is not restricted to PD but is a feature of several dementing disorders such as PDD, DLB, and frequently occurs in AD where it contributes to secondary symptoms. By contrast tauopathy is repeatedly observed in numerous disorders primarily classified as synucleinopathies and may contribute to clinical heterogeneity.

The concept of the existence of a continuum between pure synucleinopathies and tauopathies has emerged and is supported by clinical observations of a high comorbidity and overlap between neurodegenerative disorders (Figure 1), in particular between dementia and parkinsonism [9]. In this continuum theory, two proteins are central: tau and asyn. Both form abnormal intracellular inclusions, and mutations in either are sufficient to cause neurodegeneration. Recently new data has emerged which suggests that asyn and tau may interact, and that this interaction is essential for the development and spreading of neurodegeneration. In the present manuscript we discuss the recent data in line with this paradigm.

\section{Co-occurrence of tauopathies and synucleinopathies}

There are many exceptions to the classical view that asyn and tau pathology are the hallmarks of PD and AD [10], the obvious being that incidental tauopathy or synucleinopathy is sometimes observed in asymptomatic patients [11-14]. Furthermore tauopathies and synucleinopathies are not restricted to pure $\mathrm{AD}$ and $\mathrm{PD}$ respectively, but rather encompass a variety of other disorders in which co-occurrence of tau and $\alpha$ syn inclusions is frequent such as in PDD, DLB, Lewy body variant of AD (LBVAD), Guam-Parkinson-ALS dementia complex $[15,16]$ and even Down's syndrome [17] (Figure 1). Additionally, there is considerable crosstalk and comorbidity between PD and AD. For instance, PD patients are at increased risk of developing dementia [10,18-21] and more than half of $A D$ patients have Lewy bodies at autopsy, particularly in the amygdala [17,22-24], with the presence of Lewy bodies correlating with faster and more aggressive pathology [25]. In sporadic PD, neurofibrillary tangles have been repeatedly described over the past century [26-29] and synaptic-enriched fractions of AD, PD, and DLB brains have been shown to contain high levels of S396 phosphotau and phospho- $\alpha$ syn [30]. Interestingly, dementia and pronounced tau pathology have been described in familial cases of parkinsonism linked to asyn gene (SNCA) mutations [31-34]. In addition, in other familial forms of parkinsonism linked to PARKIN or LRRK2 gene mutations, the inconsistent accumulation of tau, asyn, neither, or both proteins has been observed [10,35].

In PD and PDD cases with tauopathy, phospho-tau is restricted to striatal tissues and dopaminergic neurons $[36,37]$ and some studies even co-localized tau and $\alpha$ syn in the same aggregates. For instance in PD and DLB cases, phospho-tau and $\alpha$ syn were sometimes found together in neurofibrillary tangles, Lewy bodies and neurites $[38,39]$. In one study using mass spectrometry, tau was found as a component of Lewy bodies in addition to tubulin and other cytoskeletal proteins [40]. However at the molecular level, $\alpha$ syn and tau were shown to segregate into different fibrillar species within one single aggregate [38].

\section{SNCA and MAPT in genetic studies}

It is fascinating to observe that familial cases carrying mutations in the microtubule-associated protein tau $(M A P T)$ or SNCA genes can phenotypically present with a combination of both parkinsonism and dementia. For instance, familial forms of parkinsonism due to asyn 


\section{A - Tau protein}

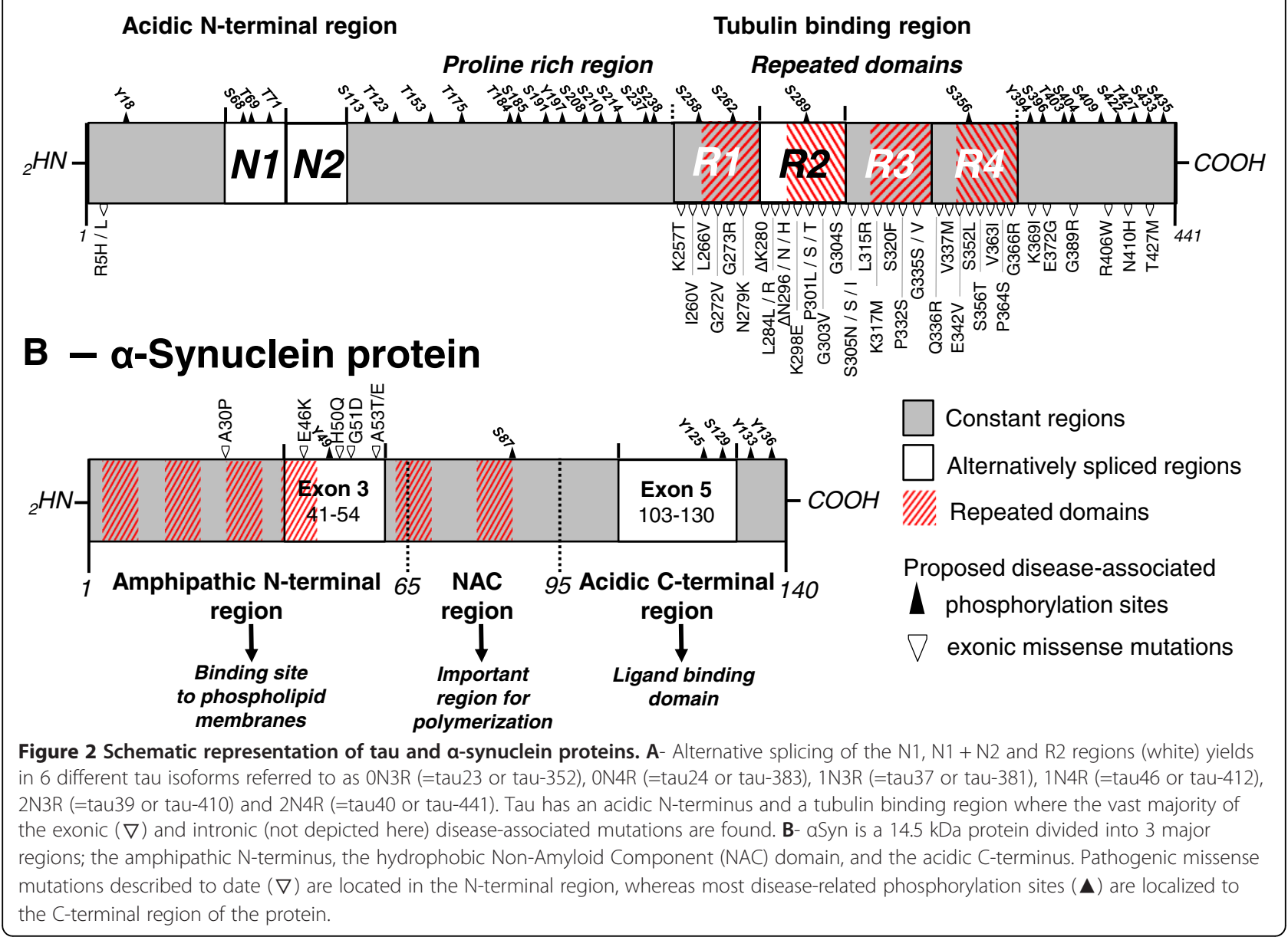

pathogenic substitutions (A30P, E46K, H50Q, G51D or A53T) or due to the duplication or triplication of the wild-type (wt) SNCA gene commonly present with additional atypical clinical signs such as hallucinations, cognitive impairment, and dementia [32,35,41-47].

Mutations in the MAPT gene also cause a variety of neurodegenerative phenotypes including parkinsonism. Pathogenicity of MAPT splice-site and missense mutations such as G272V, N279K, P301L, V337M and R406W were first reported to cause FTDP-17 $\mathrm{T}$ in 1998 (Figure 2) [48-52] followed by the description of many other intronic and exonic mutations (for reviews [53-56]). While most of the mutations such as P301L and N279K primarily cause familial FTD [50,57], other phenotypes such as CBD [58,59], PSP [60] and variable extent of parkinsonism have been observed in some patients and families with MAPT mutations. Whereas the S305N mutation provokes FTD with minimal parkinsonism [61], the K369I mutation is responsible for L-DOPA sensitive parkinsonism [62] and the deltaN296 mutation is related to familial atypical PSP [63]. Surprisingly, even single
MAPT mutations cause considerable phenotypic heterogeneity even within a single family, with a diverse combination of symptoms and age of onset [64]. This apparent randomization of the symptoms raises some questions about the exact role and specificity of tau in neurodegeneration and suggests that tau is a trigger for diverse neurodegenerative cascades. Interestingly, no consistent synuclein pathology has been reported in FTDP-17 T patients. The presence of tauopathy combined with the absence of Lewy bodies in FTDP-17 $\mathrm{T}$ and post-encephalitic parkinsonism cases suggests that tau alone is sufficient to provoke severe neurodegeneration leading to parkinsonism $[65,66]$. However, the absence of macroscopic Lewy bodies does not exclude a role for $\alpha$ syn in the form of discrete oligomers.

Recently, large-scale unbiased population-based genotyping studies have attempted to associate disease susceptibility with common genetic variants. For PD, genome-wide association studies have identified at least 24 loci so far [67]. Among them, regions encompassing the GAK, HLA$D R B 5$, SNCA, LRRK2 and MAPT genes were the most significant hits [68-70]. The observation that common genetic 

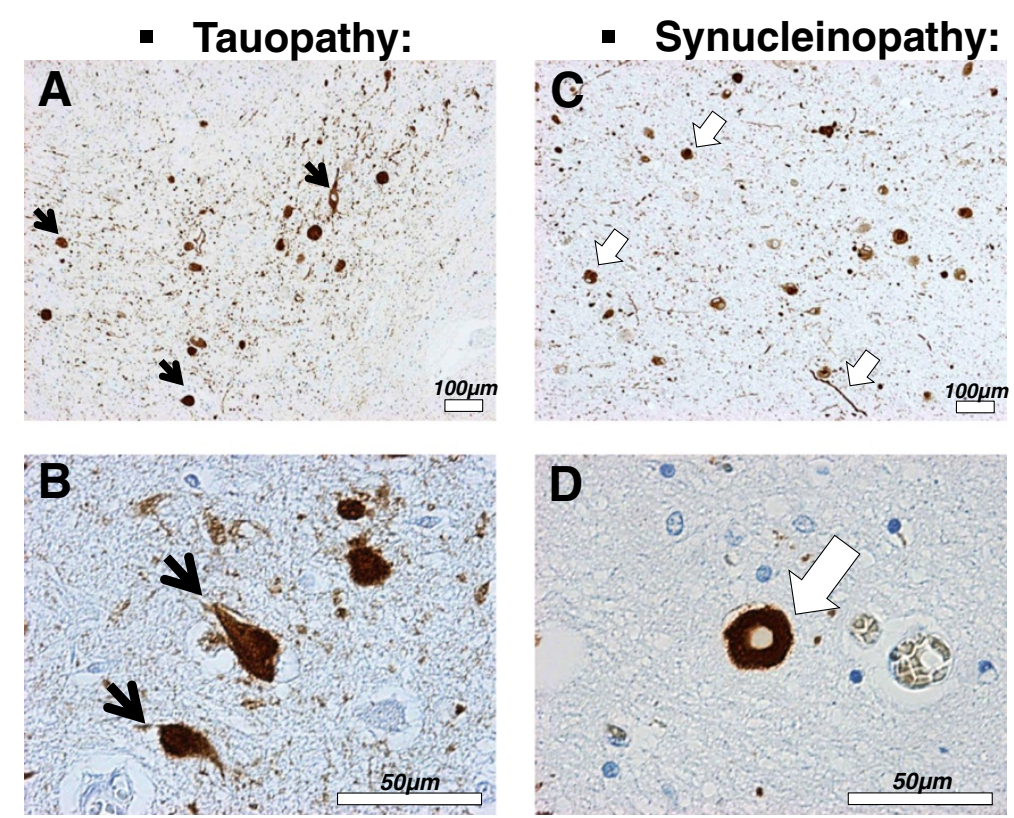

Figure 3 Tau and a-synuclein pathologies. A to D- Histological sections from the amygdala of DLB patients immunostained with an antibody against phosphorylated tau (PHF-1, Abcam, \#ab66275) (A and B) or an antibody against phosphorylated asyn (pSyn\#64, Wako, \#015-25191) ( $C$ and D). Abnormal proteinaceous inclusions of phosphorylated tau protein, called neurofibrillary tangles ( $\mathbf{A}$ and $\mathbf{B}, \mathbf{Y})$ ), and of asyn protein, called Lewy bodies and neurites ( $C$ and $\mathbf{D}, \boldsymbol{\square}$ ) are often found in neurons of the amygdala in DLB patients.

variation in the SNCA and MAPT loci associates with susceptibility to disease supports a role for these genes in not only rare familial cases but also in sporadic PD. Common genetic variations at the MAPT locus can on the whole be divided in two major haplogroups named $\mathrm{H} 1$ and $\mathrm{H} 2$ that arose due to an ancient $\sim 900 \mathrm{~kb}$ chromosome inversion. In comparison to $\mathrm{H} 1$, the $\mathrm{H} 2$ haplotype has been shown to correlate with lower expression of tau protein and to have a protective effect in neurodegeneration [71]. The MAPT $\mathrm{H} 1$ haplotype is therefore considered a genetic risk factor for a myriad of neurodegenerative disorders, including both pure tauopathies (PSP [60] and CBD [72-74]) and synucleinopathies (PD [75], PDD [76,77] and MSA [78]). However, the $\mathrm{H} 1$ haplotype is very polymorphic and the specific genetic variants that associate with risk for each disorder are still not clearly defined.

In DLB, although no significant association of the $M A P T$ locus with disease susceptibility was found in a recent genome-wide association study [79], correlation between $\mathrm{H} 1$ haplotype and the degree of synuclein pathology in the brainstem was observed in a small neuropathological study [80]. The SNCA single nucleotide polymorphism (SNP) rs2572324 has been correlated with the extent of neocortical Lewy body and neurofibrillary pathology [81]. These observations indicate that tau and asyn may influence their reciprocal aggregation and suggest that their interaction is a determining factor for the development of dementia and parkinsonism. Other genetic/epidemiological studies have also indirectly linked
$M A P T /$ tau with PD. For instance, a SNP located within the RIT2 gene, was recently nominated through a metaanalysis of genome-wide association studies. GTP-binding protein Rit2 binds to calmodulin 1 (phosphorylase kinase, delta), which also binds to both tau and asyn [68]. Increased PD susceptibility was also associated with two SNPs in the GSK3 $\beta$ gene, an established tau kinase [82], although these results could not be confirmed in a subsequent study or within the genome-wide association efforts [83]. Interestingly some epidemiological studies have also tried to determine if there is an evidence of an epistatic interaction between genetic variation of the $S N C A$ and $M A P T$ loci. An additive or even multiplicative effect between polymorphisms in SNCA and MAPT would be expected if both genes interact within the same pathogenic pathway. One study did suggest a synergistic increase in the susceptibility of developing dementia in patients with PD when a SNCA risk allele was analyzed with $M A P T \mathrm{H} 1 / \mathrm{H} 2$ inversion polymorphism [76]. Conversely, no synergistic effect for SNCA and MAPT (or LRRK2) polymorphisms were found to increase PD susceptibility in two other epidemiological studies $[84,85]$ and one meta-analysis [86].

\section{Tau and a-synuclein in vivo models} Toxin-based rodent models

Prior to the discovery of the genetic forms of disease, i.e. mutations of $M A P T$ and $S N C A$, toxin-based rodent models characterized in vivo parkinsonism research. The 
discovery that dopaminergic mid-brain neurons are especially sensitive to oxidative stress inducers such as 1-methyl-4-phenyl-1,2,3,6-tetrahydropyridine (MPTP), 6-hydroxydopamine (6-OHDA), rotenone, and paraquat resulted in the creation of toxin-based rodent models to study parkinsonian phenotype in vivo (for review [87]). Interestingly, some studies also reported the accumulation of hyperphosphorylated tau in rodents after the systemic delivery of rotenone, paraquat, and MPTP, but not maneb [88-90]. In rotenone treated rats, Hoglinger and colleagues described fibrillar structures composed of $15 \mathrm{~nm}$ straight filaments positive for phospho-tau, thioflavin $\mathrm{S}$, nitrosamine, and ubiquitin [89]. Insoluble and phosphorylated tau has been described in mice treated with MPTP [88] and Duka and colleagues demonstrated that MPTP treatment induces tau hyperphosphorylation on the S396 and S404 residues via GSK3 $\beta$ kinase in wt but not in $\alpha$ syn knock-out (KO) mice [91]. Later, Qureshi and Paudel confirmed that $\alpha$ syn presence is required for the MPTPinduced phosphorylation of tau at S214, S262, S396 and S404 residues and identified GSK3 $\beta$ and PKA as the responsible kinases [92]. However, a connection between tauopathy and synucleinopathy has not been consistently observed in these PD toxin-based models. In an interesting study by Morris and colleagues, a reduction of tau expression did not prevent 6-OHDA neurotoxicity [93]. These apparently contradictory results demonstrate that the interplay between tau and $\alpha$ syn is complex.

\section{aSyn and tau viral overexpression in rodents}

The effect of targeted human $\alpha$ syn and tau protein expression has been investigated using viral vectors-based models. In these models, co-occurrence of tau and $\alpha$ syn pathologies has also been observed. For instance, in rats, asyn overexpression induced by stereotaxic injection of lentivirus increases phospho-tau levels [94]. On the contrary, rats transduced with tau and mutant P301L tau display an increase of $\alpha$ syn and phospho- $\alpha$ syn levels [95]. In another study using adeno-associated vectors for gene transfer into the substantia nigra of rats, overexpression of human wt and P301L tau, but not $\alpha$ syn, provoked dopaminergic neurodegeneration, reduced striatal dopamine content, and motor deficit as measured by amphetamine-stimulated rotational behavior [96]. In this study behavioral dysfunction preceded the formation of neurofibrillary tangles suggesting that mature neurofibrillary tangles are not required for tau-induced disruption of dopaminergic transmission [96].

\section{Tau and asyn genetic mouse models}

Numerous genetically modified mice that overexpress the human tau and/or asyn proteins have been generated and are used to model specific aspects of the human diseases. Interestingly, tau transgenic models not only develop cognitive changes but also motor dysfunction. Mice overexpressing the mutant K369I tau develop L-DOPA sensitive parkinsonism [62], and overexpression of the pathogenic P301L and P301S forms of tau in mice provoke severe motor dysfunctions that recapitulate some of their effects in humans $[97,98]$. In the P301L tau overexpressing mouse line, inhibition of tau hyperphosphorylation by treatment with a non-specific protein kinase inhibitor also prevents the motor impairments suggesting that tau could be a target in degenerative movement disorders [99].

Likewise, cognitive deficits and tauopathy have been observed in asyn-overexpressing PD models [100-103]. Interestingly different extents of tauopathy and cognitive impairment were observed depending on the promoter type used for asyn overexpression and the species of asyn expressed. The presence of hyperphosphorylated tau was clearly identified in a wt $\alpha$ syn overexpressing transgenic mouse line using the PDGF- $\beta$ promoter at 11 months of age $[101,102]$. Nonetheless, no tauopathy was observed at 18 months in a transgenic line overexpressing wt $\alpha$ syn under the prion promoter unless this line was crossed with a P301L tau mouse [100]. Interestingly, in two other lines also using the prion promoter to overexpress the A53T and E46K mutant forms of asyn, abundant tau inclusions were observed without the need of crossing with the P301L tau expressing line [100,104,105]. The E46K line was reported to have more tau threads than the A53T asyn overexpressing transgenic line suggesting mutation-induced differences [104]. In these mice, tauopathy was restricted to areas with abundant $\alpha$ syn expression and initiated simultaneously with synucleinopathy in an age-dependent fashion, although not always localized within the same cells [100]. In the PDGF- $\beta$-wt- $\alpha$ syn mice, hyperphosphorylated tau was primarily found in the brainstem and in the striatum [101,102]. Kaul and colleagues correlated phospho-tau occurrence with the activation of ERK and JNK but not of GSK3 $\beta$ and p38MAPK kinases, whereas Haggerty and colleagues noted a match between the presence of phospho-tau and phosphoGSK3 $\beta$. Similarly, in the prion promoter driven A53T asyn mice, as well as in patients harboring the A53T mutation, hyperphosphorylated and non-soluble tau accumulated in the striatum and was correlated with increased levels of phospho-GSK3 $\beta[105,106]$. In contrast, in a Thy-1 promoter driven A30P asyn overexpressing transgenic mouse line, hyperphosphorylated and nonsoluble tau accumulated in the brainstem in correlation with increased phospho-JNK level [107]. Jointly, these observations suggest the existence of complex region- and time-dependent interactions between kinases, asyn and tau.

Some groups also crossed different transgenic mouse models to trigger the co-occurrence of tauopathy and 
synucleinopathy with the final aim to better model complex human disorders like DLB. For instance, a quadruple transgenic mouse line has been generated by crossing a triple transgenic mouse that overexpresses human ADcausing M146V presenilin-1, APP Swedish mutation, and the FTDP-17 T-causing P301L tau with a transgenic mouse that overexpresses human PD-causing A53T asyn [108]. Co-overexpression of these pathogenic proteins had a strong synergistic effect on neurodegeneration, protein aggregation, and on cognitive and motor deficits. In contrast, crossing of a Thy1 promoter driven human wt asyn overexpressing mouse line with a tau $\mathrm{KO}$ or tau conditional $\mathrm{KO}$ mouse did not prevent neurotoxicity indicating that $\alpha$ syn also acts independently from tau [93].

Several tau- and $\alpha$ syn- deficient mouse lines have been generated to determine if any particular phenotype or resistance to neurodegeneration might be present. Generally, tau- or asyn-deficient mice are viable with only minor phenotypic differences [109-112]. Remarkably, cognitive alterations were observed in an $\alpha$ - and $\gamma$-synuclein double $\mathrm{KO}$ mouse line suggesting that both proteins have a compensatory role on cognition [103]. Conversely, in aged tau-deficient animals minor motor deficits were observed in correlation with an iron accumulation and loss of dopaminergic neurons in the substantia nigra [113], but could not be reproduced in a subsequent study [112]. Together these data demonstrate that the absence of both proteins does not appear to have observable significant impact, perhaps due to compensatory mechanisms, whereas their overexpression, in particular in their mutated forms, recapitulates some aspects of the human pathologies. This is in line with a gain of toxic function mechanism and validates therapeutic strategies aimed at clearing tau and/or $\alpha$ syn for parkinsonism and/ or dementia.

\section{Non-vertebrate models}

In addition to rodents, non-vertebrate $\alpha$ syn and/or tau transgenic in vivo models have been developed. These models work surprisingly well and present many practical aspects $[114,115]$. For example, in Caenorhabditis elegans, expression of the human $\alpha$ syn or tau protein in neurons recapitulates key features of the human diseases such as motor deficits and neuronal and dendritic loss [116]. Human asyn expression in Drosophila melanogaster also induces neurotoxicity as well as L-DOPAsensitive motor deficits and formation of asyn-positive fibrils [117]. Remarkably, whereas asyn expression provokes the formation of Lewy body-like aggregates in D. melanogaster but not in C. elegans, tau expression conversely leads to the formation of insoluble inclusions in C. elegans but not in D. melanogaster $[115,116]$. Nonetheless, both proteins are neurotoxic in both models demonstrating that the formation of protein aggregates is fundamentally unnecessary for toxicity. In line with this idea, dopaminergic neurons in asyn expressing $D$. melanogaster were rescued without suppressing the presence of $\alpha$ syn inclusions by co-expression of the Hsp70 chaperone [118]. More recently, co-expression of tau and asyn in D. melanogaster has been shown to induce motor dysfunction, dopaminergic denervation, cytotoxicity, formation of abnormal ubiquitin positive inclusions, axonal transport disruption, and cytoskeletal and synaptic disorganization [119]. Tau affected dopaminergic cell count only when co-expressed with asyn, demonstrating the existence of a synergistic deleterious effect between tau and $\alpha$ syn once more. However, in contrast to what was observed in rodent models, the mechanism of toxicity in $D$. melanogaster was linked to severe cytoskeletal and axonal disorganization and subsequent synaptic alterations rather than $\alpha$ syn-promoted tau hyperphosphorylation [119].

Interesting findings have also been made in yeast models. In Saccharomyces cerevisiae, overexpressing human tau does not induce significant toxicity $[120,121]$. However, coexpression of tau with human $\alpha$ syn leads to greater toxicity than asyn expression alone, and also leads to the formation of insoluble hyperphosphorylated tau and $\alpha$ syn aggregates. The synergistic deleterious effects were increased by expression of A53T asyn or P301L tau instead of their wt forms $[120,122]$. Finally, in these models, yeast orthologs of the cyclin-dependent kinase 5 and GSK3 $\beta$ kinases were shown to be involved in the phosphorylation of tau and in the $\alpha$ syn plus tau induced-toxicity $[120,122]$.

In various transgenic or toxin-induced PD models ranging from mice to yeast, the existence of a deleterious and emulative action between tau and $\alpha$ syn has been repetitively shown. This corroborates what has been observed in humans (see Co-occurrence of tauopathies and synucleinopathies and $S N C A$ and $M A P T$ in genetic studies sections) and reinforces the idea that the interplay between $\alpha$ syn and tau are pivotal in the neurodegenerative process. Nonetheless, results from these in vivo models have to be interpreted with caution. For instance, there is no ortholog gene of the human SNCA in the fly, worm or yeast, whereas in rodents the endogenous wt asyn carries the A53T mutation without deleterious effect $[123,124]$. Moreover, in rodents, tau hyperphosphorylation can occur in instances of hibernation or starvation, making this pathological hallmark difficult to interpret $[125,126]$.

\section{Tau and a-synuclein in molecular studies}

The fact that $\alpha$ syn and tau can physically interact with each other was demonstrated by Jensen and colleagues in 1999. In this pioneering study, tau protein from brain lysates was pulled down by asyn affinity chromatography. The authors also noted a strong effect of ionic strength on the binding, indicating the implication of 
salt bridges in the interaction [127]. Moreover, in line with an interaction under physiological conditions, a binding IC50 value of 50pM was calculated between tau and asyn using plasmon surface resonance and a radioactive binding assay [127]. At the cellular level, tau and asyn were co-localized in the same cellular compartments and in particular in axons [127]. This was confirmed by Förster resonance energy transfer (FRET) in more recent studies $[128,129]$.

\section{Docking sites and effects of mutations on tau - asyn interactions}

Several studies have tried to identify the exact regions and the critical amino acid residues by which tau and $\alpha$ syn interact. Using protein fragmentation and recombinant peptides, Jensen and colleagues found that the interacting domains are localized to the C-terminus of $\alpha$ syn (55 to 140) and the microtubule binding region of tau (192 to 383) [127]. Accordingly two subsequent studies found that the N-terminal (1 to 153) and C-terminal (352 to 441) fragments of tau do not interact with $\alpha$ syn $[129,130]$. The question of the role of phosphorylation and diseaserelated mutations in the tau and $\alpha$ syn interaction has also been addressed and investigated in vitro. Phosphorylation of the serine 214 residue of tau was identified to increase asyn binding [92]. In contrast, phospho-mimic/dead mutations at the serine 129 residue of $\alpha$ syn had no effect [129]. No effect of A30P and A53T asyn disease-related mutations was initially reported [127], but later in a study using FRET, the asyn mutation A30P, but not the A53T and E46K, was shown to reduce association of asyn with tau [129]. Conversely, in a third study using coimmunoprecipitation, asyn mutations A30P, A53T, E46K but not E83P increased binding with tau [92], E83P being an artificial mutation in the NAC domain that blocks $\alpha$ syn aggregation [131]. On the contrary, the P301L tau mutation was found to reduce interaction with asyn [130]. Consequently the exact role of the disease-related mutations on tau and $\alpha$ syn interaction still needs to be clarified especially since in vivo observations suggest that they may play a role.

\section{Tau - asyn - kinases}

The promotion of tau hyperphosphorylation by asyn has been demonstrated in several studies and could be a mechanism that explains how asyn triggers tauopathy (Figure 4). An in vitro study showed that asyn promotes tau phosphorylation at S262 and S356 residues via PKA [127]. Later, another tau kinase, GSK3 $\beta$, was found to be recruited and activated in an asyn-dependent manner and provoke tau hyperphosphorylation at T181, S396, and 5404 residues $[88,91,120,132]$. This effect seems to be the result of both an increase GSK3 $\beta$ kinase activity $[91,105]$ and the formation of a tripartite GSK3 $\beta$ - $\alpha$ syn- tau complex with tau binding to the acidic C-terminus of $\alpha$ syn, and GSK3 $\beta$ to the NAC and KTEGV domains of asyn [132]. However, it has also been shown that similar to $\alpha$ syn, $\beta$ - and $\gamma$-synuclein can also induce GSK3 $\beta$ autophosphorylation and that $\beta$-synuclein could even promote tau phosphorylation, questioning the specificity of this mechanism and its physiological relevance [132]. Nonetheless other facts reinforce the idea of a link between GSK3 $\beta$, tau and $\alpha$ syn. For instance, in a cellular MPTP model, GSK3 $\beta$ inhibition with lithium or TDZD-8 was able to decrease tau phosphorylation but also $\alpha$ syn accumulation and cell death [91]. However GSK3 $\beta$ is not the only kinase that links $\alpha$ syn with hyperphosphorylated tau. Indeed, activation of ERK and JNK, that also phosphorylate tau at S396 and S404 residues, correlate with the presence of phospho-tau in $\alpha$ syn overexpressing transgenic mouse models [102,106,107]. In addition, tau phosphorylation at S262 and S356 residues by PKA is exacerbated by asyn in vitro [127]. Following this, PKA was identified as the responsible kinase for the $\alpha$ syn-dependent phosphorylation of tau at S262 residue after MPTP treatment in cells [92]. Interestingly, PKA does not phosphorylate tau at S396 and S404 residues, whereas GSK3 $\beta$ does not phosphorylate tau at S262 residue suggesting that both kinases probably have an additive role in the induction of tauopathy by asyn (Figure 4). Recently, tau has been identified as a putative substrate for the PD-related kinase LRRK2 $[133,134]$ and genetic correction of the PD-related LRRK2 G2019S mutation in human induced pluripotent stem cells resulted in a decreased tau and asyn expression [135], linking tau once more to PD.

\section{Tau - asyn - tubulin}

$\alpha$ Syn may trigger tauopathy through the destabilization of the tau-tubulin interaction, which results in both tau aggregation and cytoskeleton disorganization (Figure 4). Interestingly, the 14-3-3 protein that shares some homology with asyn [136] has also been found to bind to tau and cause tubulin instability [137]. Tau binding to tubulin is reduced by both direct competition with asyn and indirectly by asyn-promoted tau hyperphosphorylation [127]. Nevertheless the overall role of $\alpha$ syn on cytoskeleton modeling is difficult to interpret. Indeed, similar to tau, wt but not mutant $\alpha$ syn is capable of binding to tubulin and promoting tubulin polymerization [138-140]. Overexpression of A30P, A53T, E46K but not E83P mutated $\alpha$ syn has been shown to decrease microtubule stability and promote phosphorylation of tau at the S262 residue by PKA [92]. Involvement of asyn in cytoskeleton stability was also demonstrated by the disruptive effect of treatment with microtubule-destabilizing agents such as colchicine, nocodazole and vinblastine on the tubulin- $\alpha$ syn interaction $[129,141]$. Interestingly it was recently shown that seeds of asyn dose-dependently reduce tau-promoted microtubule 


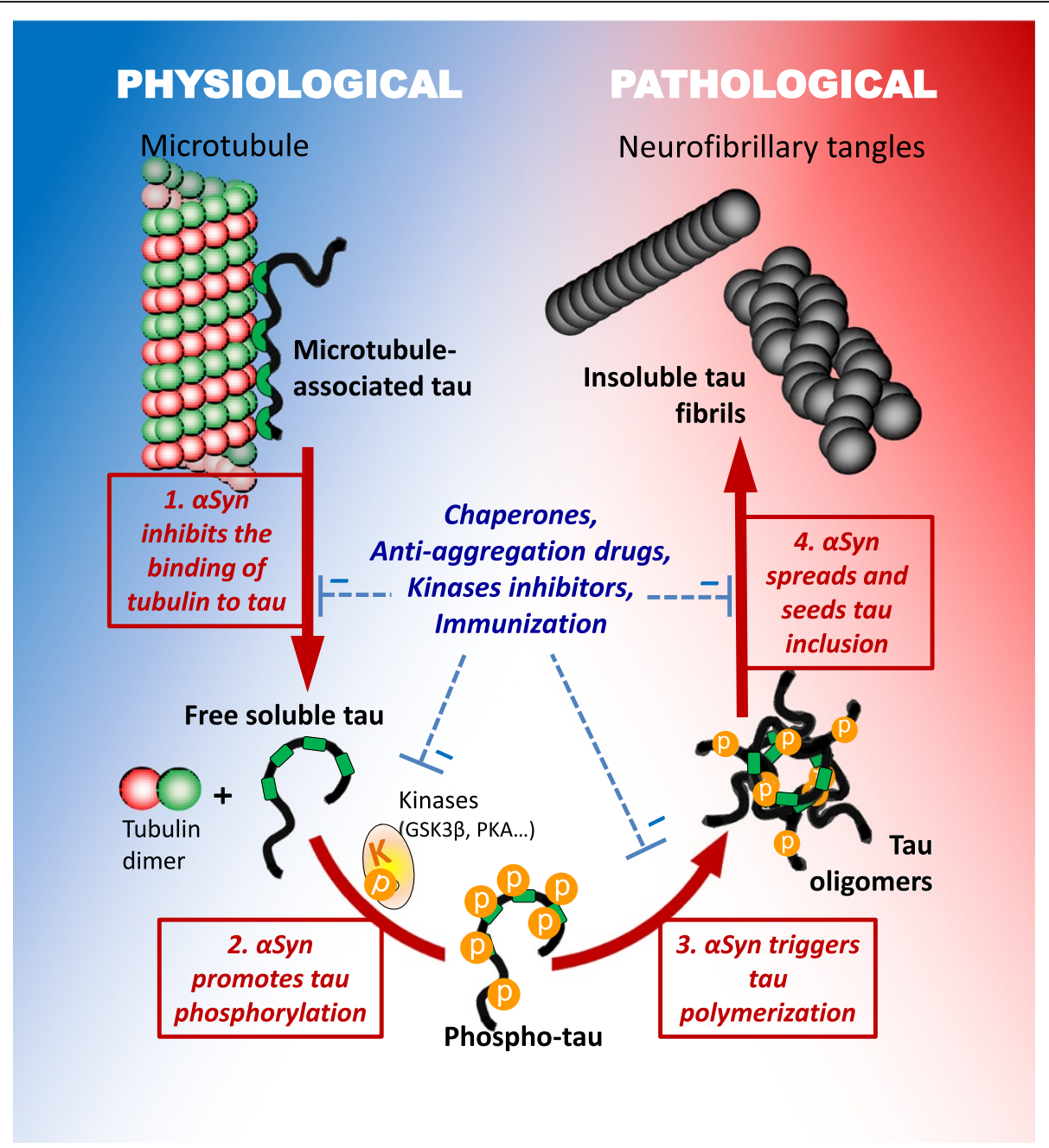

Figure 4 Putative pathways of deleterious tau and a-synuclein interactions. Interaction of tau and asyn may promote pathogenesis via distinct mechanisms. 1. aSyn may block the normal interaction between tau and tubulin by directly binding to tau and tubulin and thereby interfering with tau physiological function. 2. aSyn could recruit kinases and promote the hyperphosphorylation of tau. 3. aSyn may also catalyze tau polymerization and trigger the formation of tau/asyn co-oligomers. 4. Finally, asyn oligomers or fibrils may seed tau fibrillization and thereby initiate and propagate tauopathy.

assembly, whereas asyn oligomers impair microtubulekinesin interplay [142].

\section{Co-aggregation and seeding}

In the last few years, effort has been directed at unravelling the mechanisms by which neurodegeneration progresses in the brain. In $\mathrm{PD}$ and $\mathrm{AD}$, neurodegeneration and protein aggregation overlap with each other and seem to follow a preset path giving the impression of spreading [3]. Moreover, the existence of a prion-like cell-to-cell propagation mechanism has been suggested by the unexpected post mortem observation that $\alpha$ syn aggregates spread to healthy transplanted neurons in PD patients $[143,144]$. Consistently, infection of healthy cells by a seeding mechanism similar to the self-templating activity of prions has been shown in vitro and in vivo using polymerized asyn and tau [145-154]. Moreover, asyn and tau have been shown to be excreted from cells via non-conventional mechanisms and are found in exosomes $[155,156]$.

In this perspective, a major difference between tau and

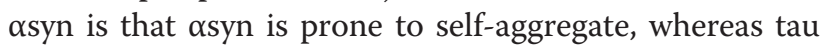
cannot aggregate by itself and requires an inducing agent [157]. This has raised the question of whether asyn could initiate tau aggregation; indeed, in 2003, Giasson and colleagues demonstrated that $\alpha$ syn and tau promote each other's aggregation in vitro. Whereas the six alternative spliced variants of tau were able to aggregate in the presence of full length wt $\alpha$ syn, tau aggregation was neither promoted by the delta71-82 truncated form of 
$\alpha$ syn, nor by $\beta$-synuclein, nor by amyloidogenic $A \beta$ peptide [100]. These observations demonstrate that tau accelerates $\alpha$ syn polymerization and that $\alpha$ syn can act as an inducing agent of tau polymerization through its hydrophobic NAC region. Interestingly, mutant A53T asyn was shown to have increased tau fibrillization properties in vitro when compared to wt asyn [33]. Conversely, tau expression enhanced toxicity and secretion, and changed the pattern of asyn aggregation by promoting the formation of smaller inclusions in cellular models [128].

Using the fluorescent intensity distribution analysis technique (FIDA), Nübling and colleagues have shown that tau and $\alpha$ syn can form co-oligomers and that coaggregation happens even at nanomolar concentrations but only in the presence of a cationic aggregation inducer such as $\mathrm{Al}^{3+}$ and $\mathrm{Fe}^{3+}$ or DMSO [158]. Moreover, tau phosphorylation by GSK3 $\beta$ strongly enhanced the formation of mixed oligomers [158]. However electron microscopy revealed that co-incubation of monomeric tau and asyn mainly leads to the formation of homopolymeric fibrils [100]. This is consistent with the observations made in DLB cases [38] and suggests that asyn and tau predominantly interact with each other at the monomeric and oligomeric stages. More recently, a series of studies tried to reproduce these in vitro findings in vivo by demonstrating that exogenous $\alpha$ syn can be taken up by neurons and induce the formation of intracellular Lewy body-like structures $[159,160]$ and also hyperphosphorylated tau aggregates [151,161]. For instance extracellular treatment with polymerized recombinant human asyn induced the formation of insoluble phosphorylated tau in cellular models $[104,161]$. Counterintuitively, wt asyn fibrils were more efficient than E46K asyn fibrils at cross-seeding tau [104].

\section{Conclusions and future directions}

The overlap and numerous similarities between synucleinopathies and tauopathies suggest that therapeutic strategies that target common processes of tau and asyn aggregation could benefit patients across a spectrum of neurodegenerative disorders, and may be particularly relevant for the treatment of secondary symptoms such as cognitive impairment in PD or secondary parkinsonism in dementia. In the present review we have compiled data from the literature linking tau and asyn. The repeated in vitro and in vivo observations that tau and asyn interact highly suggest that $\alpha$ syn and tau play as teammates, however how this interaction occurs and affects neurodegenerative processes is still not fully elucidated and several scenarios are possible (Figure 4).

$\alpha$ Syn was initially shown to bind to tau and interfere with the normal interaction between tau and tubulin [127]. The disruption of the normal physiological interaction between tau and tubulin for a pathological interaction between tau and asyn could explain why asyn and tau interaction seems to be deleterious. However, more recent data suggest that the role of tau and asyn interaction on cytoskeleton modeling, axonal development and synaptic activity in neurons may be more complex as first thought $[119,140,142]$. Additional mechanisms, acting together in a vicious cycle, may explain how asyn triggers tau aggregation and vice versa. Reciprocal promotion of phosphorylation is probably a key player, suggesting that kinases could be used as targets. GSK3 $\beta$ inhibition for instance was concomitantly able to decrease tau phosphorylation, $\alpha$ syn accumulation and cell death in a cellular MPTP model [91]. In a P301L tau overexpressing mouse line, inhibition of tau hyperphosphorylation by treatment with a non-specific protein kinase inhibitor prevented motor impairments [99].

A mechanistic cross-seeding effect based on templating of a pathological $\beta$-sheet conformation is also highly suspected [151,159-161]. Indeed, $\alpha$ syn and tau can form co-oligomers that catalyze aggregation and finally lead to the formation of pure homofibrils $[100,158]$. This resembles the prion self-propagation mechanism and this parallel is now commonly drawn in the literature, even if there is no evidence of human-to-human transmission for asyn or tau $[162,163]$. However, mutual misfolding is probably the first event that leads to asyn and tau synergistic co-aggregation. The fact that $\alpha$ syn has homology with the 14-3-3 co-chaperone protein, a known partner of tau and $\alpha$ syn, and is able to substitute 14-3-3 co-chaperone activity on 14-3-3 targets supports this hypothesis [136,137]. In this regard upregulation of chaperone proteins is another promising strategy that is presently being investigated to restore the normal conformation of $\alpha$ syn and tau (Figure 4). Heat shock proteins (HSPs) increase the association of tau with microtubules and regulate tau degradation, ubiquitination and phosphorylation [164,165]. Hsp70 preferentially binds to tau oligomers and restores anterograde fast axonal transport [166]. Our group has demonstrated that $\alpha$ syn aggregation can be blocked by modulating different chaperones including Hsp27, Hsp70, Hsp90, torsinA and CHIP [167-175]. HSPs have been shown to positively act on $\alpha$ syn or on tau independently, but they may also have a neuroprotective effect by restoring and regulating the normal interaction between both proteins [130,132].

Observations suggest that $\alpha$ syn being a trigger of tauopathy is more plausible than the opposite scenario. For instance, whereas the presence of tau only accelerated asyn polymerization, co-incubation with $\alpha$ syn was necessary to trigger tau aggregation in vitro [100]. Consistently, tau ablation failed to prevent neurotoxicity in the 6-OHDA or wt asyn overexpressing mouse models 
[125]. Furthermore, pronounced tauopathy has been described in $\alpha$ syn transgenic mice [100-102,104,105] and in PD patients harboring the A53T mutation [31,33,34], whereas no consistent $\alpha$ syn pathology has been reported in tau transgenic mice or FTDP-17 $\mathrm{T}$ patients [66]. However, this is somewhat contradicted by the observation that asyn pathology in $\mathrm{AD}$ is more pronounced than the tau pathology in PD [16,22-24,26-29,37].

Nonetheless, even if some gray areas persist regarding the mechanisms and roles of the interaction between tau and $\alpha$ syn, applications and future directions are already emerging. One future development is the identification of reliable biomarkers for efficient diagnosis of neurodegenerative disorders at the prodromal stage. In addition to other proteins, $\alpha$ syn and tau are presently being developed as cerebrospinal fluid biomarkers for improved clinical diagnoses. Cerebrospinal fluid levels of $A \beta$, total and phospho- $\alpha$ syn, and total and phospho-tau change differentially depending on the nature of the disease. Consequently, looking at the ratios between these proteins could enable clinicians to determine the risk of developing $\mathrm{PD}, \mathrm{AD}$, or a mixed disorder such as DLB and provide them the needed therapeutic window to start preventive and tailor-made treatments [176].

\section{Abbreviations \\ AD: Alzheimer's disease; ALS: Amyotrophic lateral sclerosis; asyn: Alpha-synuclein protein; DLB: Dementia with Lewy bodies; CBD: Corticobasal degeneration; FRET: Förster resonance energy transfer; FTDP-17 T: Frontotemporal dementia with parkinsonism linked to tau mutations on chromosome 17; GSK3B: Glycogen synthase kinase 3 beta; Hsps: Heat shock proteins; JNK: c-Jun N-terminal kinases; KO: Knock-out; LRRK2: Leucine reach repeat kinase 2; MAPK: Mitogen-activated protein kinase; MAPT: Tau gene; MPTP: 1-methyl-4-phenyl-1:2:3:6- tetrahydropyridine; MSA: Multiple system atrophy; PD: Parkinson's disease; PDD: Parkinson's disease with dementia; PiD: Pick's disease; PKA: Protein kinase A; PSP: Progressive supranuclear palsy; SNCA: asyn gene; SNP: Single nucleotide polymorphisms; wt: Wild-type.}

\section{Competing interests}

The authors declare that they have no competing interests.

\section{Authors' contributions}

SM and PJM wrote and drafted the manuscript. DRJ, ELML, MD and OAR added intellectual input and editorial suggestions, and assisted in figure preparation. All authors read and approved the final manuscript.

\section{Acknowledgements}

This work was supported by the Mayo Clinic and the NIH NS063963. OAR is partially supported by NINDS R01\# NS078086 and Mayo Clinic Florida is a Morris K. Udall Parkinson's Disease Research Center of Excellence (NINDS P50 \#NS072187). The authors would like to thank A.-M. Baine, A. Bradshaw, A. Bronnhuber, Dr. M. Gan, Dr. W. Springer, Dr. F. Fiesel, Dr. C. Labbé, Dr. P. M. Tacik, Dr. M. G. Plumot and Dr. K. F. Bieniek for passionate scientific discussions.

Received: 3 April 2014 Accepted: 16 October 2014 Published: 29 October 2014

\section{References}

1. Weintraub D, Comella CL, Horn S: Parkinson's disease-part 1: pathophysiology, symptoms, burden, diagnosis, and assessment. Am J Manag Care 2008, 14:S40-S48.

2. Weintraub D, Comella CL, Horn S: Parkinson's disease-part 2: treatment of motor symptoms. Am J Manag Care 2008, 14:S49-S58.
3. Braak H, Rub U, Gai WP, Del Tredici K: Idiopathic Parkinson's disease: possible routes by which vulnerable neuronal types may be subject to neuroinvasion by an unknown pathogen. J Neural Transm 2003, 110:517-536.

4. Jones DR, Moussaud S, McLean P: Targeting heat shock proteins to modulate alpha-synuclein toxicity. Ther Adv Neurol Disord 2014, 7:33-51.

5. Spillantini MG, Schmidt ML, Lee VM, Trojanowski JQ, Jakes R, Goedert M: Alpha-synuclein in Lewy bodies. Nature 1997, 388:839-840.

6. Irizarry MC, Growdon W, Gomez-Isla T, Newell K, George JM, Clayton DF, Hyman BT: Nigral and cortical Lewy bodies and dystrophic nigral neurites in Parkinson's disease and cortical Lewy body disease contain alpha-synuclein immunoreactivity. J Neuropathol Exp Neurol 1998, 57:334-337.

7. Spillantini MG, Crowther RA, Jakes R, Cairns NJ, Lantos PL, Goedert M: Filamentous alpha-synuclein inclusions link multiple system atrophy with Parkinson's disease and dementia with Lewy bodies. Neurosci Lett 1998, 251:205-208.

8. Brion JP, Couck AM, Passareiro E, Flament-Durand J: Neurofibrillary tangles of Alzheimer's disease: an immunohistochemical study. J Submicrosc Cytol 1985, 17:89-96.

9. Irwin DJ, Lee VM, Trojanowski JQ: Parkinson's disease dementia: convergence of alpha-synuclein, tau and amyloid-beta pathologies. Nat Rev Neurosci 2013, 14:626-636.

10. Galpern WR, Lang AE: Interface between tauopathies and synucleinopathies: a tale of two proteins. Ann Neurol 2006, 59:449-458.

11. Dickson DW, Fujishiro H, DelleDonne A, Menke J, Ahmed Z, Klos KJ, Josephs KA, Frigerio R, Burnett M, Parisi JE, Ahlskog JE: Evidence that incidental Lewy body disease is pre-symptomatic Parkinson's disease. Acta Neuropathol 2008, 115:437-444.

12. Evidente VG, Adler CH, Sabbagh MN, Connor DJ, Hentz JG, Caviness JN, Sue LI, Beach TG: Neuropathological findings of PSP in the elderly without clinical PSP: possible incidental PSP? Parkinsonism Relat Disord 2011, 17:365-371.

13. Mikolaenko I, Pletnikova O, Kawas CH, O'Brien R, Resnick SM, Crain B, Troncoso JC: Alpha-synuclein lesions in normal aging, Parkinson disease, and Alzheimer disease: evidence from the Baltimore Longitudinal Study of Aging (BLSA). J Neuropathol Exp Neurol 2005, 64:156-162.

14. Saito Y, Kawashima A, Ruberu NN, Fujiwara H, Koyama S, Sawabe M, Arai T, Nagura H, Yamanouchi H, Hasegawa M, Iwatsubo T, Murayama S: Accumulation of phosphorylated alpha-synuclein in aging human brain. J Neuropathol Exp Neurol 2003, 62:644-654.

15. Forman MS, Schmidt ML, Kasturi S, Perl DP, Lee VM, Trojanowski JQ: Tau and alpha-synuclein pathology in amygdala of Parkinsonism-dementia complex patients of Guam. Am J Pathol 2002, 160:1725-1731.

16. Lippa CF, Fujiwara H, Mann DM, Giasson B, Baba M, Schmidt ML, Nee LE, O'Connell B, Pollen DA, St George-Hyslop P, Ghetti B, Nochlin D, Bird TD, Cairns NJ, Lee VM, Iwatsubo T, Trojanowski JQ: Lewy bodies contain altered alpha-synuclein in brains of many familial Alzheimer's disease patients with mutations in presenilin and amyloid precursor protein genes. Am J Pathol 1998, 153:1365-1370.

17. Lippa CF, Schmidt ML, Lee VM, Trojanowski JQ: Antibodies to alpha-synuclein detect Lewy bodies in many Down's syndrome brains with Alzheimer's disease. Ann Neurol 1999, 45:353-357.

18. Aarsland D, Zaccai J, Brayne C: A systematic review of prevalence studies of dementia in Parkinson's disease. Mov Disord 2005, 20:1255-1263.

19. Braak H, Rub U, Jansen Steur EN, Del Tredici K, de Vos RA: Cognitive status correlates with neuropathologic stage in Parkinson disease. Neurology 2005, 64:1404-1410.

20. Hurtig HI, Trojanowski JQ, Galvin J, Ewbank D, Schmidt ML, Lee VM, Clark CM, Glosser G, Stern MB, Gollomp SM, Arnold SE: Alpha-synuclein cortical Lewy bodies correlate with dementia in Parkinson's disease. Neurology 2000, 54:1916-1921.

21. Leverenz JB, Quinn JF, Zabetian C, Zhang J, Montine KS, Montine TJ: Cognitive impairment and dementia in patients with Parkinson disease. Curr Top Med Chem 2009, 9:903-912.

22. Hamilton RL: Lewy bodies in Alzheimer's disease: a neuropathological review of 145 cases using alpha-synuclein immunohistochemistry. Brain Pathol 2000, 10:378-384.

23. Leverenz JB, Fishel MA, Peskind ER, Montine TJ, Nochlin D, Steinbart E, Raskind MA, Schellenberg GD, Bird TD, Tsuang D: Lewy body pathology in familial Alzheimer disease: evidence for disease- and mutation-specific pathologic phenotype. Arch Neurol 2006, 63:370-376. 
24. Leverenz JB, Hamilton R, Tsuang DW, Schantz A, Vavrek D, Larson EB, Kukull WA, Lopez O, Galasko D, Masliah E, Kaye J, Woltjer R, Clark C, Trojanowsk $J Q$, Montine TJ: Empiric refinement of the pathologic assessment of Lewy-related pathology in the dementia patient. Brain Pathol 2008, 18:220-224.

25. Kraybill ML, Larson EB, Tsuang DW, Teri L, McCormick WC, Bowen JD, Kukull WA, Leverenz JB, Cherrier MM: Cognitive differences in dementia patients with autopsy-verified AD, Lewy body pathology, or both. Neurology 2005, 64:2069-2073

26. Bancher $C$, Braak H, Fischer $P$, Jellinger KA: Neuropathological staging of Alzheimer lesions and intellectual status in Alzheimer's and Parkinson's disease patients. Neurosci Lett 1993, 162:179-182.

27. Joachim CL, Morris JH, Kosik KS, Selkoe DJ: Tau antisera recognize neurofibrillary tangles in a range of neurodegenerative disorders. Ann Neurol 1987, 22:514-520.

28. Lewy FH: Paralysis agitans. Pathologische Anatomie Handbuch der Neurologie (Ed M Lewandowsky) Julius Springer 1912, 3:920-933.

29. Schneider JA, Li JL, Li Y, Wilson RS, Kordower JH, Bennett DA: Substantia nigra tangles are related to gait impairment in older persons. Ann Neurol 2006, 59:166-173.

30. Muntane G, Dalfo E, Martinez A, Ferrer I: Phosphorylation of tau and alpha-synuclein in synaptic-enriched fractions of the frontal cortex in Alzheimer's disease, and in Parkinson's disease and related alpha-synucleinopathies. Neuroscience 2008, 152:913-923.

31. Duda JE, Giasson BI, Mabon ME, Miller DC, Golbe LI, Lee VM, Trojanowski JQ: Concurrence of alpha-synuclein and tau brain pathology in the Contursi kindred. Acta Neuropathol 2002, 104:7-11.

32. Fujioka S, Ogaki K, Tacik PM, Uitti RJ, Ross OA, Wszolek ZK: Update on novel familial forms of Parkinson's disease and multiple system atrophy. Parkinsonism Relat Disord 2014, 20(Suppl 1):S29-S34.

33. Kotzbauer PT, Giasson BI, Kravitz AV, Golbe LI, Mark MH, Trojanowski JQ, Lee VM: Fibrillization of alpha-synuclein and tau in familial Parkinson's disease caused by the A53T alpha-synuclein mutation. Exp Neurol 2004, 187:279-288.

34. Yamaguchi K, Cochran EJ, Murrell JR, Polymeropoulos MH, Shannon KM, Crowther RA, Goedert M, Ghetti B: Abundant neuritic inclusions and microvacuolar changes in a case of diffuse Lewy body disease with the A53T mutation in the alpha-synuclein gene. Acta Neuropathol 2005, 110:298-305.

35. Poulopoulos M, Levy OA, Alcalay RN: The neuropathology of genetic Parkinson's disease. Mov Disord 2012, 27:831-842.

36. Jellinger KA: Interaction between alpha-synuclein and tau in Parkinson's disease comment on Wills et al.: elevated tauopathy and alpha-synuclein pathology in postmortem Parkinson's disease brains with and without dementia. Exp Neurol 2010; 225: 210-218. Exp Neurol 2011, 227:13-18.

37. Wills J, Jones J, Haggerty T, Duka V, Joyce JN, Sidhu A: Elevated tauopathy and alpha-synuclein pathology in postmortem Parkinson's disease brains with and without dementia. Exp Neurol 2010, 225:210-218.

38. Arima K, Mizutani $T$, Alim MA, Tonozuka-Uehara H, Izumiyama $Y$, Hirai $S$, Ueda K: NACP/alpha-synuclein and tau constitute two distinctive subsets of filaments in the same neuronal inclusions in brains from a family of parkinsonism and dementia with Lewy bodies: double-immunolabeling fluorescence and electron microscopic studies. Acta Neuropathol 2000 100:115-121.

39. Ishizawa T, Mattila P, Davies P, Wang D, Dickson DW: Colocalization of tau and alpha-synuclein epitopes in Lewy bodies. J Neuropathol Exp Neurol 2003, 62:389-397.

40. Leverenz JB, Umar I, Wang Q, Montine TJ, McMillan PJ, Tsuang DW, Jin J, Pan C, Shin J, Zhu D, Zhang J: Proteomic identification of novel proteins in cortical lewy bodies. Brain Pathol 2007, 17:139-145.

41. Appel-Cresswell S, Vilarino-Guell C, Encarnacion M, Sherman H, Yu I, Shah B, Weir D, Thompson C, Szu-Tu C, Trinh J, Aasly JO, Rajput A, Rajput AH, Jon Stoessl A, Farrer MJ: Alpha-synuclein p.H50Q, a novel pathogenic mutation for Parkinson's disease. Mov Disord 2013, 28:811-813.

42. Chartier-Harlin MC, Kachergus J, Roumier C, Mouroux V, Douay X, Lincoln S, Levecque C, Larvor L, Andrieux J, Hulihan M, Waucquier N, Defebvre L, Amouyel P, Farrer M, Destee A: Alpha-synuclein locus duplication as a cause of familial Parkinson's disease. Lancet 2004, 364:1167-1169.

43. Kiely AP, Asi YT, Kara E, Limousin P, Ling H, Lewis P, Proukakis C, Quinn N, Lees AJ, Hardy J, Revesz T, Houlden H, Holton JL: alpha-Synucleinopathy associated with G51D SNCA mutation: a link between Parkinson's disease and multiple system atrophy? Acta Neuropathol 2013, 125:753-769.

44. Kruger R, Kuhn W, Muller T, Woitalla D, Graeber M, Kosel S, Przuntek H, Epplen JT, Schols L, Riess O: Ala30Pro mutation in the gene encoding alpha-synuclein in Parkinson's disease. Nat Genet 1998, 18:106-108.

45. Polymeropoulos MH, Lavedan C, Leroy E, Ide SE, Dehejia A, Dutra A, Pike B, Root H, Rubenstein J, Boyer R, Stenroos ES, Chandrasekharappa S, Athanassiadou A, Papapetropoulos T, Johnson WG, Lazzarini AM, Duvoisin RC, Di lorio G, Golbe LI, Nussbaum RL: Mutation in the alpha-synuclein gene identified in families with Parkinson's disease. Science 1997, 276:2045-2047.

46. Singleton $A B$, Farrer $M$, Johnson J, Singleton A, Hague S, Kachergus J, Hulihan M, Peuralinna T, Dutra A, Nussbaum R, Lincoln S, Crawley A, Hanson M, Maraganore D, Adler C, Cookson MR, Muenter M, Baptista M, Miller D, Blancato J, Hardy J, Gwinn-Hardy K: alpha-Synuclein locus triplication causes Parkinson's disease. Science 2003, 302:841.

47. Zarranz JJ, Alegre J, Gomez-Esteban JC, Lezcano E, Ros R, Ampuero I, Vidal L, Hoenicka J, Rodriguez O, Atares B, Llorens V, Gomez Tortosa E, del Ser T, Munoz DG, de Yebenes JG: The new mutation, E46K, of alpha-synuclein causes Parkinson and Lewy body dementia. Ann Neurol 2004, 55:164-173.

48. Clark LN, Poorkaj P, Wszolek Z, Geschwind DH, Nasreddine ZS, Miller B, Li D, Payami H, Awert F, Markopoulou K, Andreadis A, D'Souza I, Lee VM, Reed L, Trojanowski JQ, Zhukareva V, Bird T, Schellenberg G, Wilhelmsen KC: Pathogenic implications of mutations in the tau gene in pallido-pontonigral degeneration and related neurodegenerative disorders linked to chromosome 17. Proc Natl Acad Sci U S A 1998, 95:13103-13107.

49. Dumanchin C, Camuzat A, Campion D, Verpillat $P$, Hannequin D, Dubois $B$, Saugier-Veber P, Martin C, Penet C, Charbonnier F, Agid Y, Frebourg T, Brice A: Segregation of a missense mutation in the microtubule-associated protein tau gene with familial frontotemporal dementia and parkinsonism. Hum Mol Genet 1998, 7:1825-1829.

50. Hutton M, Lendon CL, Rizzu P, Baker M, Froelich S, Houlden H, PickeringBrown S, Chakraverty S, Isaacs A, Grover A, Hackett J, Adamson J, Lincoln S, Dickson D, Davies P, Petersen RC, Stevens M, de Graaff E, Wauters E, van Baren J, Hillebrand M, Joosse M, Kwon JM, Nowotny P, Che LK, Norton J, Morris JC, Reed LA, Trojanowski J, Basun H, et al: Association of missense and 5 '-splice-site mutations in tau with the inherited dementia FTDP-17. Nature 1998, 393:702-705.

51. Poorkaj P, Bird TD, Wijsman E, Nemens E, Garruto RM, Anderson L, Andreadis A, Wiederholt WC, Raskind M, Schellenberg GD: Tau is a candidate gene for chromosome 17 frontotemporal dementia. Ann Neurol 1998, 43:815-825.

52. Spillantini MG, Murrell JR, Goedert M, Farlow MR, Klug A, Ghetti B: Mutation in the tau gene in familial multiple system tauopathy with presenile dementia. Proc Natl Acad Sci U S A 1998, 95:7737-7741.

53. D'Souza I, Schellenberg GD: Regulation of tau isoform expression and dementia. Biochim Biophys Acta 2005, 1739:104-115.

54. Gendron TF, Petrucelli L: The role of tau in neurodegeneration. Mol Neurodegener 2009, 4:13.

55. Liu F, Gong CX: Tau exon 10 alternative splicing and tauopathies. Mol Neurodegener 2008, 3:8.

56. Spillantini MG, Goedert M: Tau pathology and neurodegeneration. Lancet Neurol 2013, 12:609-622.

57. Arima K, Kowalska A, Hasegawa M, Mukoyama M, Watanabe R, Kawai M, Takahashi K, Iwatsubo T, Tabira T, Sunohara N: Two brothers with frontotemporal dementia and parkinsonism with an N279K mutation of the tau gene. Neurology 2000, 54:1787-1795.

58. Di Maria E, Tabaton M, Vigo T, Abbruzzese G, Bellone E, Donati C, Frasson E, Marchese R, Montagna P, Munoz DG, Pramstaller PP, Zanusso G, Ajmar F, Mandich P: Corticobasal degeneration shares a common genetic background with progressive supranuclear palsy. Ann Neurol 2000, 47:374-377.

59. Kouri N, Carlomagno Y, Baker M, Liesinger AM, Caselli RJ, Wszolek ZK Petrucelli L, Boeve BF, Parisi JE, Josephs KA, Uitti RJ, Ross OA, Graff-Radford NR, Deture MA, Dickson DW, Rademakers R: Novel mutation in MAPT exon 13 (p.N410H) causes corticobasal degeneration. Acta Neuropathol 2014, 127:271-282.

60. Baker M, Litvan I, Houlden H, Adamson J, Dickson D, Perez-Tur J, Hardy J, Lynch T, Bigio $E$, Hutton M: Association of an extended haplotype in the tau gene with progressive supranuclear palsy. Hum Mol Genet 1999, 8:711-715.

61. lijima M, Tabira T, Poorkaj P, Schellenberg GD, Trojanowski JQ, Lee VM, Schmidt ML, Takahashi K, Nabika T, Matsumoto T, Yamashita Y, Yoshioka S, 
Ishino $\mathrm{H}$ : A distinct familial presenile dementia with a novel missense mutation in the tau gene. Neuroreport 1999, 10:497-501.

62. Ittner LM, Fath T, Ke YD, Bi M, van Eersel J, Li KM, Gunning P, Gotz J: Parkinsonism and impaired axonal transport in a mouse model of frontotemporal dementia. Proc Natl Acad Sci U S A 2008, 105:15997-16002.

63. Rossi G, Gasparoli E, Pasquali C, Di Fede G, Testa D, Albanese A, Bracco F, Tagliavini F: Progressive supranuclear palsy and Parkinson's disease in a family with a new mutation in the tau gene. Ann Neurol 2004, 55:448.

64. van Herpen E, Rosso SM, Serverijnen LA, Yoshida H, Breedveld G, van de Graaf R, Kamphorst W, Ravid R, Willemsen R, Dooijes D, Majoor-Krakauer D, Kros JM, Crowther RA, Goedert M, Heutink P, van Swieten JC: Variable phenotypic expression and extensive tau pathology in two families with the novel tau mutation L315R. Ann Neurol 2003, 54:573-581.

65. Jellinger KA: Absence of alpha-synuclein pathology in postencephalitic parkinsonism. Acta Neuropathol 2009, 118:371-379.

66. Lee VM, Giasson BI, Trojanowski JQ: More than just two peas in a pod: common amyloidogenic properties of tau and alpha-synuclein in neurodegenerative diseases. Trends Neurosci 2004, 27:129-134

67. Nalls MA, Pankratz N, Lill CM, Do CB, Hernandez DG, Saad M, DeStefano AL, Kara E, Bras J, Sharma M, Schulte C, Keller MF, Arepalli S, Letson C, Edsall C, Stefansson H, Liu X, Pliner H, Lee JH, Cheng R, Ikram MA, loannidis JP, Hadjigeorgiou GM, Bis JC, Martinez M, Perlmutter JS, Goate A, Marder K, Fiske B, Sutherland M, et al: Large-scale meta-analysis of genome-wide association data identifies six new risk loci for Parkinson's disease. Nat Genet 2014, 46:989-993.

68. Labbe C, Ross OA: Association studies of sporadic Parkinson's disease in the genomic era. Curr Genomics 2014, 15:2-10.

69. Simon-Sanchez J, Schulte C, Bras JM, Sharma M, Gibbs JR, Berg D, Paisan-Ruiz C, Lichtner P, Scholz SW, Hernandez DG, Kruger R, Federoff M, Klein C, Goate A, Perlmutter J, Bonin M, Nalls MA, Illig T, Gieger C, Houlden H, Steffens M, Okun MS, Racette BA, Cookson MR, Foote KD, Fernandez HH, Traynor BJ, Schreiber S, Arepalli S, Zonozi R, et al: Genome-wide association study reveals genetic risk underlying Parkinson's disease. Nat Genet 2009, 41:1308-1312.

70. Spencer CC, Plagnol V, Strange A, Gardner M, Paisan-Ruiz C, Band G, Barker RA, Bellenguez C, Bhatia K, Blackburn H, Blackwell JM, Bramon E, Brown MA, Burn D, Casas JP, Chinnery PF, Clarke CE, Corvin A, Craddock N, Deloukas P, Edkins S, Evans J, Freeman C, Gray E, Hardy J, Hudson G, Hunt S, Jankowski J, Langford C, Lees AJ, et al: Dissection of the genetics of Parkinson's disease identifies an additional association $5^{\prime}$ of SNCA and multiple associated haplotypes at 17q21. Hum Mol Genet 2011, 20:345-353.

71. Wade-Martins R: Genetics: the MAPT locus-a genetic paradigm in disease susceptibility. Nat Rev Neurol 2012, 8:477-478.

72. Caffrey TM, Wade-Martins R: The role of MAPT sequence variation in mechanisms of disease susceptibility. Biochem Soc Trans 2012, 40:687-692.

73. Houlden H, Baker M, Morris HR, MacDonald N, Pickering-Brown S, Adamson J, Lees AJ, Rossor MN, Quinn NP, Kertesz A, Khan MN, Hardy J, Lantos PL, St George-Hyslop P, Munoz DG, Mann D, Lang AE, Bergeron C, Bigio EH, Litvan I, Bhatia KP, Dickson D, Wood NW, Hutton M: Corticobasal degeneration and progressive supranuclear palsy share a common tau haplotype. Neurology 2001, 56:1702-1706.

74. Pittman AM, Myers AJ, Abou-Sleiman P, Fung HC, Kaleem M, Marlowe L, Duckworth J, Leung D, Williams D, Kilford L, Thomas N, Morris CM, Dickson D, Wood NW, Hardy J, Lees AJ, de Silva R: Linkage disequilibrium fine mapping and haplotype association analysis of the tau gene in progressive supranuclear palsy and corticobasal degeneration. J Med Genet 2005, 42:837-846.

75. Zabetian CP, Hutter CM, Factor SA, Nutt JG, Higgins DS, Griffith A, Roberts $J W$, Leis BC, Kay DM, Yearout D, Montimurro JS, Edwards KL, Samii A, Payami $\mathrm{H}$ : Association analysis of MAPT $\mathrm{H} 1$ haplotype and subhaplotypes in Parkinson's disease. Ann Neurol 2007, 62:137-144.

76. Goris A, Williams-Gray CH, Clark GR, Foltynie T, Lewis SJ, Brown J, Ban M, Spillantini MG, Compston A, Burn DJ, Chinnery PF, Barker RA, Sawcer SJ: Tau and alpha-synuclein in susceptibility to, and dementia in, Parkinson's disease. Ann Neurol 2007, 62:145-153.

77. Williams-Gray CH, Evans JR, Goris A, Foltynie T, Ban M, Robbins TW, Brayne C, Kolachana BS, Weinberger DR, Sawcer SJ, Barker RA: The distinct cognitive syndromes of Parkinson's disease: 5 year follow-up of the CamPalGN cohort. Brain 2009, 132:2958-2969.

78. Vilarino-Guell C, Soto-Ortolaza Al, Rajput A, Mash DC, Papapetropoulos S, Pahwa R, Lyons KE, Uitti RJ, Wszolek ZK, Dickson DW, Farrer MJ, Ross OA:
MAPT $\mathrm{H} 1$ haplotype is a risk factor for essential tremor and multiple system atrophy. Neurology 2011, 76:670-672.

79. Bras J, Guerreiro R, Darwent L, Parkkinen L, Ansorge O, Escott-Price V, Hernandez DG, Nalls MA, Clark LN, Honig LS, Marder K, Van Der Flier WM, Lemstra A, Scheltens P, Rogaeva E, St George-Hyslop P, Londos E, Zetterberg H, Ortega-Cubero S, Pastor P, Ferman TJ, Graff-Radford NR, Ross OA, Barber I, Braae A, Brown K, Morgan K, Maetzler W, Berg D, Troakes C, et al: Genetic analysis implicates APOE, SNCA and suggests lysosomal dysfunction in the etiology of dementia with Lewy bodies. Hum Mol Genet 2014, in press.

80. Colom-Cadena M, Gelpi E, Marti MJ, Charif S, Dols-lcardo O, Blesa R, Clarimon J, Lleo A: MAPT H1 haplotype is associated with enhanced alpha-synuclein deposition in dementia with Lewy bodies. Neurobiol Aging 2013, 34:936-942.

81. Peuralinna T, Oinas M, Polvikoski T, Paetau A, Sulkava R, Niinisto L, Kalimo H, Hernandez D, Hardy J, Singleton A, Tienari PJ, Myllykangas L: Neurofibrillary tau pathology modulated by genetic variation of alpha-synuclein. Ann Neurol 2008, 64:348-352.

82. Kwok JB, Hallupp M, Loy CT, Chan DK, Woo J, Mellick GD, Buchanan DD, Silburn PA, Halliday GM, Schofield PR: GSK3B polymorphisms alter transcription and splicing in Parkinson's disease. Ann Neurol 2005, 58:829-839.

83. Wider C, Vilarino-Guell C, Heckman MG, Jasinska-Myga B, Ortolaza-Soto Al, Diehl NN, Crook JE, Cobb SA, Bacon JA, Aasly JO, Gibson JM, Lynch T, Uitti RJ, Wszolek ZK, Farrer MJ, Ross OA: SNCA, MAPT, and GSK3B in Parkinson disease: a gene-gene interaction study. Eur J Neurol 2011, 18:876-881.

84. Biernacka JM, Armasu SM, Cunningham JM, Ahlskog JE, Chung SJ, Maraganore DM: Do interactions between SNCA, MAPT, and LRRK2 genes contribute to Parkinson's disease susceptibility? Parkinsonism Relat Disord 2011, 17:730-736.

85. Mamah CE, Lesnick TG, Lincoln SJ, Strain KJ, de Andrade M, Bower JH, Ahlskog JE, Rocca WA, Farrer MJ, Maraganore DM: Interaction of alpha-synuclein and tau genotypes in Parkinson's disease. Ann Neurol 2005, 57:439-443.

86. Elbaz A, Ross OA, loannidis JP, Soto-Ortolaza Al, Moisan F, Aasly J, Annesi G, Bozi M, Brighina L, Chartier-Harlin MC, Destee A, Ferrarese C, Ferraris A, Gibson JM, Gispert S, Hadjigeorgiou GM, Jasinska-Myga B, Klein C, Kruger R, Lambert JC, Lohmann K, van de Loo S, Loriot MA, Lynch T, Mellick GD, Mutez E, Nilsson C, Opala G, Puschmann A, Quattrone A, et al: Independent and joint effects of the MAPT and SNCA genes in Parkinson disease. Ann Neurol 2011, 69:778-792.

87. Bove J, Perier C: Neurotoxin-based models of Parkinson's disease. Neuroscience 2012, 211:51-76.

88. Duka T, Rusnak M, Drolet RE, Duka V, Wersinger C, Goudreau JL, Sidhu A: Alpha-synuclein induces hyperphosphorylation of Tau in the MPTP model of parkinsonism. Faseb J 2006, 20:2302-2312.

89. Hoglinger GU, Lannuzel A, Khondiker ME, Michel PP, Duyckaerts C, Feger J Champy P, Prigent A, Medja F, Lombes A, Oertel WH, Ruberg M, Hirsch EC: The mitochondrial complex I inhibitor rotenone triggers a cerebral tauopathy. J Neurochem 2005, 95:930-939.

90. Wills J, Credle J, Oaks AW, Duka V, Lee JH, Jones J, Sidhu A: Paraquat, but not maneb, induces synucleinopathy and tauopathy in striata of mice through inhibition of proteasomal and autophagic pathways. PLOS One 2012, 7:e30745.

91. Duka T, Duka V, Joyce JN, Sidhu A: Alpha-Synuclein contributes to GSK-3beta-catalyzed Tau phosphorylation in Parkinson's disease models. Faseb J 2009, 23:2820-2830.

92. Qureshi HY, Paudel HK: Parkinsonian neurotoxin 1-methyl-4-phenyl-1,2,3,6tetrahydropyridine (MPTP) and alpha-synuclein mutations promote Tau protein phosphorylation at Ser262 and destabilize microtubule cytoskeleton in vitro. J Biol Chem 2011, 286:5055-5068.

93. Morris M, Koyama A, Masliah E, Mucke L: Tau reduction does not prevent motor deficits in two mouse models of Parkinson's disease. PLOS One 2011, 6:e29257.

94. Khandelwal PJ, Dumanis SB, Feng LR, Maguire-Zeiss K, Rebeck G, Lashuel HA, Moussa CE: Parkinson-related parkin reduces alpha-Synuclein phosphorylation in a gene transfer model. Mol Neurodegener 2010, 5:47.

95. Khandelwal PJ, Dumanis SB, Herman AM, Rebeck GW, Moussa CE: Wild type and P301L mutant Tau promote neuro-inflammation and alpha-Synuclein accumulation in lentiviral gene delivery models. Mol Cell Neurosci 2012, 49:44-53. 
96. Klein RL, Dayton RD, Lin WL, Dickson DW: Tau gene transfer, but not alpha-synuclein, induces both progressive dopamine neuron degeneration and rotational behavior in the rat. Neurobiol Dis 2005, 20:64-73.

97. Allen B, Ingram E, Takao M, Smith MJ, Jakes R, Virdee K, Yoshida H, Holzer M, Craxton M, Emson PC, Atzori C, Migheli A, Crowther RA, Ghetti B, Spillantini MG, Goedert M: Abundant tau filaments and nonapoptotic neurodegeneration in transgenic mice expressing human P301S tau protein. J Neurosci 2002, 22:9340-9351.

98. Lewis J, McGowan E, Rockwood J, Melrose H, Nacharaju P, Van Slegtenhorst M, Gwinn-Hardy K, Paul Murphy M, Baker M, Yu X, Duff K, Hardy J, Corral A, Lin WL, Yen SH, Dickson DW, Davies P, Hutton M: Neurofibrillary tangles, amyotrophy and progressive motor disturbance in mice expressing mutant (P301L) tau protein. Nat Genet 2000, 25:402-405

99. Le Corre S, Klafki HW, Plesnila N, Hubinger G, Obermeier A, Sahagun H, Monse B, Seneci P, Lewis J, Eriksen J, Zehr C, Yue M, McGowan E, Dickson DW, Hutton M, Roder HM: An inhibitor of tau hyperphosphorylation prevents severe motor impairments in tau transgenic mice. Proc Natl Acad Sci U S A 2006, 103:9673-9678.

100. Giasson Bl, Forman MS, Higuchi M, Golbe LI, Graves CL, Kotzbauer PT, Trojanowski JQ, Lee VM: Initiation and synergistic fibrillization of tau and alpha-synuclein. Science 2003, 300:636-640.

101. Haggerty T, Credle J, Rodriguez O, Wills J, Oaks AW, Masliah E, Sidhu A: Hyperphosphorylated Tau in an alpha-synuclein-overexpressing transgenic model of Parkinson's disease. Eur J Neurosci 2011, 33:1598-1610.

102. Kaul T, Credle J, Haggerty T, Oaks AW, Masliah E, Sidhu A: Region-specific tauopathy and synucleinopathy in brain of the alpha-synuclein overexpressing mouse model of Parkinson's disease. BMC Neurosci 2011, 12:79.

103. Magen I, Chesselet MF: Mouse models of cognitive deficits due to alpha-synuclein pathology. J Parkinsons Dis 2011, 1:217-227.

104. Emmer KL, Waxman EA, Covy JP, Giasson BI: E46K human alpha-synuclein transgenic mice develop Lewy-like and tau pathology associated with age-dependent, detrimental motor impairment. J Biol Chem 2011, 286:35104-35118.

105. Wills J, Credle J, Haggerty T, Lee JH, Oaks AW, Sidhu A: Tauopathic changes in the striatum of A53T alpha-synuclein mutant mouse model of Parkinson's disease. PLoS One 2011, 6:e17953.

106. Oaks AW, Frankfurt M, Finkelstein DI, Sidhu A: Age-dependent effects of A53T alpha-synuclein on behavior and dopaminergic function. PLOS One 2013, 8:e60378.

107. Frasier M, Walzer M, McCarthy L, Magnuson D, Lee JM, Haas C, Kahle P, Wolozin B: Tau phosphorylation increases in symptomatic mice overexpressing A30P alpha-synuclein. Exp Neurol 2005, 192:274-287.

108. Clinton LK, Blurton-Jones M, Myczek K, Trojanowski JQ, LaFerla FM: Synergistic interactions between Abeta, tau, and alpha-synuclein: acceleration of neuropathology and cognitive decline. J Neurosci 2010, 30:7281-7289

109. Abeliovich A, Schmitz Y, Farinas I, Choi-Lundberg D, Ho WH, Castillo PE, Shinsky N, Verdugo JM, Armanini M, Ryan A, Hynes M, Phillips H, Sulzer D, Rosenthal A: Mice lacking alpha-synuclein display functional deficits in the nigrostriatal dopamine system. Neuron 2000, 25:239-252.

110. Avila J, de Barreda EG, Fuster-Matanzo A, Simon D, Llorens-Martin M, Engel T, Lucas JJ, Diaz-Hernandez M, Hernandez F: Looking for novel functions of tau. Biochem Soc Trans 2012, 40:653-655.

111. Harada A, Oguchi K, Okabe S, Kuno J, Terada S, Ohshima T, Sato-Yoshitake $R$, Takei $Y$, Noda T, Hirokawa N: Altered microtubule organization in small-calibre axons of mice lacking tau protein. Nature 1994, 369:488-491.

112. Morris M, Hamto P, Adame A, Devidze N, Masliah E, Mucke L: Age-appropriate cognition and subtle dopamine-independent motor deficits in aged tau knockout mice. Neurobiol Aging 2013, 34:1523-1529.

113. Lei $P$, Ayton S, Finkelstein DI, Spoerri L, Ciccotosto GD, Wright DK, Wong BX, Adlard PA, Cherny RA, Lam LQ, Roberts BR, Volitakis I, Egan GF, McLean CA, Cappai R, Duce JA, Bush Al: Tau deficiency induces Parkinsonism with dementia by impairing APP-mediated iron export. Nat Med 2012, 18:291-295.

114. Dawson TM, Ko HS, Dawson VL: Genetic animal models of Parkinson's disease. Neuron 2010, 66:646-661

115. Prussing K, Voigt A, Schulz JB: Drosophila melanogaster as a model organism for Alzheimer's disease. Mol Neurodegener 2013, 8:35.

116. Teschendorf D, Link CD: What have worm models told us about the mechanisms of neuronal dysfunction in human neurodegenerative diseases? Mol Neurodegener 2009, 4:38.
117. Feany MB, Bender WW: A Drosophila model of Parkinson's disease. Nature 2000, 404:394-398.

118. Auluck PK, Chan HY, Trojanowski JQ, Lee VM, Bonini NM: Chaperone suppression of alpha-synuclein toxicity in a Drosophila model for Parkinson's disease. Science 2002, 295:865-868.

119. Roy B, Jackson GR: Interactions between Tau and alpha-synuclein augment neurotoxicity in a Drosophila model of Parkinson's disease. Hum Mol Genet 2014

120. Ciaccioli G, Martins A, Rodrigues C, Vieira H, Calado P: A powerful yeast model to investigate the synergistic interaction of alpha-synuclein and tau in neurodegeneration. PLoS One 2013, 8:e55848.

121. Vandebroek T, Terwel D, Vanhelmont T, Gysemans M, Van Haesendonck C, Engelborghs $Y$, Winderickx J, Van Leuven F: Microtubule binding and clustering of human Tau-4R and Tau-P301L proteins isolated from yeast deficient in orthologues of glycogen synthase kinase-3beta or cdk5. J Biol Chem 2006, 281:25388-25397

122. Zabrocki P, Pellens K, Vanhelmont T, Vandebroek T, Griffioen G, Wera S, Van Leuven F, Winderickx J: Characterization of alpha-synuclein aggregation and synergistic toxicity with protein tau in yeast. Febs 2005, 272:1386-1400.

123. Hamilton BA: alpha-Synuclein A53T substitution associated with Parkinson disease also marks the divergence of Old World and New World primates. Genomics 2004, 83:739-742.

124. Larsen K, Hedegaard C, Bertelsen MF, Bendixen C: Threonine 53 in alpha-synuclein is conserved in long-living non-primate animals. Biochem Biophys Res Commun 2009, 387:602-605.

125. Arendt T, Stieler J, Strijkstra AM, Hut RA, Rudiger J, Van der Zee EA Harkany T, Holzer M, Hartig W: Reversible paired helical filament-like phosphorylation of tau is an adaptive process associated with neuronal plasticity in hibernating animals. J Neurosci 2003, 23:6972-6981.

126. Yanagisawa M, Planel E, Ishiguro K, Fujita SC: Starvation induces tau hyperphosphorylation in mouse brain: implications for Alzheimer's disease. FEBS Lett 1999, 461:329-333.

127. Jensen PH, Hager H, Nielsen MS, Hojrup P, Gliemann J, Jakes R: alpha-synuclein binds to Tau and stimulates the protein kinase A-catalyzed tau phosphorylation of serine residues 262 and 356. J Biol Chem 1999 274:25481-25489.

128. Badiola N, de Oliveira RM, Herrera F, Guardia-Laguarta C, Goncalves SA, Pera M, Suarez-Calvet M, Clarimon J, Outeiro TF, Lleo A: Tau enhances alphasynuclein aggregation and toxicity in cellular models of synucleinopathy. PLoS One 2011, 6:e26609.

129. Esposito A, Dohm CP, Kermer P, Bahr M, Wouters FS: alpha-Synuclein and its disease-related mutants interact differentially with the microtubule protein tau and associate with the actin cytoskeleton. Neurobiol Dis 2007, 26:521-531.

130. Benussi L, Ghidoni R, Paterlini A, Nicosia F, Alberici AC, Signorini S, Barbiero $L$, Binetti $G$ : Interaction between tau and alpha-synuclein proteins is impaired in the presence of P301L tau mutation. Exp Cell Res 2005, 308:78-84.

131. Koo HJ, Lee $H J$, Im H: Sequence determinants regulating fibrillation of human alpha-synuclein. Biochem Biophys Res Commun 2008, 368:772-778.

132. Kawakami F, Suzuki M, Shimada N, Kagiya G, Ohta E, Tamura K, Maruyama H, Ichikawa T: Stimulatory effect of alpha-synuclein on the tau-phosphorylation by GSK-3beta. Febs J 2011, 278:4895-4904.

133. Bailey RM, Covy JP, Melrose HL, Rousseau L, Watkinson R, Knight J, Miles S, Farrer MJ, Dickson DW, Giasson BI, Lewis J: LRRK2 phosphorylates novel tau epitopes and promotes tauopathy. Acta Neuropathol 2013, 126:809-827.

134. Kawakami F, Yabata T, Ohta E, Maekawa T, Shimada N, Suzuki M, Maruyama H, Ichikawa T, Obata F: LRRK2 phosphorylates tubulin-associated tau but not the free molecule: LRRK2-mediated regulation of the tau-tubulin association and neurite outgrowth. PLoS One 2012, 7:e30834.

135. Reinhardt P, Schmid B, Burbulla LF, Schondorf DC, Wagner L, Glatza M Hoing S, Hargus G, Heck SA, Dhingra A, Wu G, Muller S, Brockmann K, Kluba T, Maisel M, Kruger R, Berg D, Tsytsyura Y, Thiel CS, Psathaki OE, Klingauf J, Kuhlmann T, Klewin M, Muller H, Gasser T, Scholer HR, Sterneckert J: Genetic correction of a LRRK2 mutation in human iPSCs links parkinsonian neurodegeneration to ERK-dependent changes in gene expression. Cell Stem Cell 2013, 12:354-367.

136. Ostrerova N, Petrucelli L, Farrer M, Mehta N, Choi P, Hardy J, Wolozin B: alpha-Synuclein shares physical and functional homology with 14-3-3 proteins. J Neurosci 1999, 19:5782-5791. 
137. Hashiguchi M, Sobue K, Paudel HK: 14-3-3zeta is an effector of tau protein phosphorylation. J Biol Chem 2000, 275:25247-25254.

138. Alim MA, Hossain MS, Arima K, Takeda K, Izumiyama Y, Nakamura M, Kaji H, Shinoda T, Hisanaga S, Ueda K: Tubulin seeds alpha-synuclein fibril formation. J Biol Chem 2002, 277:2112-2117.

139. Alim MA, Ma QL, Takeda K, Aizawa T, Matsubara M, Nakamura M, Asada A, Saito T, Kaji H, Yoshii M, Hisanaga S, Ueda K: Demonstration of a role for alpha-synuclein as a functional microtubule-associated protein. J Alzheimers Dis 2004, 6:435-442. discussion 443-439.

140. Zhou Y, Gu G, Goodlett DR, Zhang T, Pan C, Montine TJ, Montine KS, Aebersold $\mathrm{RH}$, Zhang J: Analysis of alpha-synuclein-associated proteins by quantitative proteomics. J Biol Chem 2004, 279:39155-39164.

141. Wersinger C, Sidhu A: Disruption of the interaction of alpha-synuclein with microtubules enhances cell surface recruitment of the dopamine transporter. Biochemistry 2005, 44:13612-13624.

142. Prots I, Veber V, Brey S, Campioni S, Buder K, Riek R, Bohm KJ, Winner B: alpha-Synuclein oligomers impair neuronal microtubule-kinesin interplay. J Biol Chem 2013, 288:21742-21754.

143. Kordower JH, Chu Y, Hauser RA, Freeman TB, Olanow CW: Lewy body-like pathology in long-term embryonic nigral transplants in Parkinson's disease. Nat Med 2008, 14:504-506.

144. Li JY, Englund E, Holton JL, Soulet D, Hagell P, Lees AJ, Lashley T, Quinn NP, Rehncrona S, Bjorklund A, Widner H, Revesz T, Lindvall O, Brundin P: Lewy bodies in grafted neurons in subjects with Parkinson's disease suggest host-to-graft disease propagation. Nat Med 2008, 14:501-503.

145. Clavaguera F, Akatsu H, Fraser G, Crowther RA, Frank S, Hench J, Probst A, Winkler DT, Reichwald J, Staufenbiel M, Ghetti B, Goedert M, Tolnay M: Brain homogenates from human tauopathies induce tau inclusions in mouse brain. Proc Natl Acad Sci U S A 2013, 110:9535-9540.

146. Clavaguera F, Bolmont T, Crowther RA, Abramowski D, Frank S, Probst A, Fraser G, Stalder AK, Beibel M, Staufenbiel M, Jucker M, Goedert M, Tolnay $\mathrm{M}$ : Transmission and spreading of tauopathy in transgenic mouse brain. Nat Cell Biol 2009, 11:909-913.

147. Clavaguera F, Hench J, Lavenir I, Schweighauser G, Frank S, Goedert M, Tolnay M: Peripheral administration of tau aggregates triggers intracerebral tauopathy in transgenic mice. Acta Neuropathol 2014 127:299-301.

148. Danzer KM, Haasen D, Karow AR, Moussaud S, Habeck M, Giese A, Kretzschmar H, Hengerer B, Kostka M: Different species of alpha-synuclein oligomers induce calcium influx and seeding. J Neurosci 2007, 27:9220-9232.

149. Danzer KM, Krebs SK, Wolff M, Birk G, Hengerer B: Seeding induced by alpha-synuclein oligomers provides evidence for spreading of alpha-synuclein pathology. J Neurochem 2009, 111:192-203.

150. Frost $B$, Jacks RL, Diamond MI: Propagation of tau misfolding from the outside to the inside of a cell. J Biol Chem 2009, 284:12845-12852.

151. Guo JL, Covell DJ, Daniels JP, Iba M, Stieber A, Zhang B, Riddle DM, Kwong LK, Xu Y, Trojanowski JQ, Lee VM: Distinct alpha-synuclein strains differentially promote tau inclusions in neurons. Cell 2013, 154:103-117.

152. Iba M, Guo JL, McBride JD, Zhang B, Trojanowski JQ, Lee VM: Synthetic tau fibrils mediate transmission of neurofibrillary tangles in a transgenic mouse model of Alzheimer's-like tauopathy. J Neurosci 2013, 33:1024-1037.

153. Volpicelli-Daley LA, Luk KC, Patel TP, Tanik SA, Riddle DM, Stieber A, Meaney DF, Trojanowski JQ, Lee VM: Exogenous alpha-synuclein fibrils induce Lewy body pathology leading to synaptic dysfunction and neuron death. Neuron 2011, 72:57-71.

154. Watts JC, Giles K, Oehler A, Middleton L, Dexter DT, Gentleman SM, DeArmond SJ, Prusiner SB: Transmission of multiple system atrophy prions to transgenic mice. Proc Natl Acad Sci U S A 2013, 110:19555-19560.

155. Danzer KM, Kranich LR, Ruf WP, Cagsal-Getkin O, Winslow AR, Zhu L, Vanderburg CR, McLean PJ: Exosomal cell-to-cell transmission of alpha synuclein oligomers. Mol Neurodegener 2012, 7:42.

156. Simon D, Garcia-Garcia E, Royo F, Falcon-Perez JM, Avila J: Proteostasis of tau: Tau overexpression results in its secretion via membrane vesicles. FEBS Lett 2012, 586:47-54.

157. Goedert M, Jakes R, Spillantini MG, Hasegawa M, Smith MJ, Crowther RA: Assembly of microtubule-associated protein tau into Alzheimer-like filaments induced by sulphated glycosaminoglycans. Nature 1996, 383:550-553.

158. Nubling G, Bader B, Levin J, Hildebrandt J, Kretzschmar H, Giese A Synergistic influence of phosphorylation and metal ions on tau oligomer formation and coaggregation with alpha-synuclein at the single molecule level. Mol Neurodegener 2012, 7:35.

159. Luk KC, Kehm V, Carroll J, Zhang B, O'Brien P, Trojanowski JQ, Lee VM: Pathological alpha-synuclein transmission initiates Parkinson-like neurodegeneration in nontransgenic mice. Science 2012, 338:949-953.

160. Masuda-Suzukake M, Nonaka T, Hosokawa M, Oikawa T, Arai T, Akiyama H, Mann DM, Hasegawa M: Prion-like spreading of pathological alpha-synuclein in brain. Brain 2013, 136:1128-1138.

161. Waxman EA, Giasson Bl: Induction of intracellular tau aggregation is promoted by alpha-synuclein seeds and provides novel insights into the hyperphosphorylation of tau. J Neurosci 2011, 31:7604-7618.

162. Brown P, Gajdusek DC, Gibbs CJ Jr, Asher DM: Potential epidemic of Creutzfeldt-Jakob disease from human growth hormone therapy. N Engl J Med 1985, 313:728-731.

163. Irwin DJ, Abrams JY, Schonberger LB, Leschek EW, Mills JL, Lee VM, Trojanowski JQ: Evaluation of potential infectivity of Alzheimer and Parkinson disease proteins in recipients of cadaver-derived human growth hormone. JAMA Neurol 2013, 70:462-468.

164. David DC, Layfield R, Serpell L, Narain Y, Goedert M, Spillantini MG: Proteasomal degradation of tau protein. J Neurochem 2002, 83:176-185.

165. Petrucelli L, Dickson D, Kehoe K, Taylor J, Snyder H, Grover A, De Lucia M, McGowan E, Lewis J, Prihar G, Kim J, Dillmann WH, Browne SE, Hall A, Voellmy R, Tsuboi Y, Dawson TM, Wolozin B, Hardy J, Hutton M: CHIP and $\mathrm{Hsp70}$ regulate tau ubiquitination, degradation and aggregation. Hum Mol Genet 2004, 13:703-714.

166. Patterson KR, Ward SM, Combs B, Voss K, Kanaan NM, Morfini G, Brady ST, Gamblin TC, Binder LI: Heat shock protein 70 prevents both tau aggregation and the inhibitory effects of preexisting tau aggregates on fast axonal transport. Biochemistry 2011, 50:10300-10310.

167. Klucken J, Shin Y, Masliah E, Hyman BT, McLean PJ: Hsp70 Reduces alphaSynuclein Aggregation and Toxicity. J Biol Chem 2004, 279:25497-25502.

168. McFarland NR, Dimant H, Kibuuka L, Ebrahimi-Fakhari D, Desjardins CA, Danzer KM, Danzer M, Fan Z, Schwarzschild MA, Hirst W, McLean PJ: Chronic treatment with novel small molecule Hsp90 inhibitors rescues striatal dopamine levels but not alpha-synuclein-induced neuronal cell loss. PLoS One 2014, 9:e86048.

169. McLean PJ, Kawamata H, Shariff S, Hewett J, Sharma N, Ueda K, Breakefield $X O$, Hyman BT: TorsinA and heat shock proteins act as molecular chaperones: suppression of alpha-synuclein aggregation. J Neurochem 2002, 83:846-854

170. McLean PJ, Klucken J, Shin Y, Hyman BT: Geldanamycin induces Hsp70 and prevents alpha-synuclein aggregation and toxicity in vitro. Biochem Biophys Res Commun 2004, 321:665-669.

171. Outeiro TF, Klucken J, Strathearn KE, Liu F, Nguyen P, Rochet JC, Hyman BT, McLean PJ: Small heat shock proteins protect against alpha-synucleininduced toxicity and aggregation. Biochem Biophys Res Commun 2006, 351:631-638.

172. Putcha P, Danzer KM, Kranich LR, Scott A, Silinski M, Mabbett S, Hicks CD, Veal JM, Steed PM, Hyman BT, McLean PJ: Brain-permeable small-molecule inhibitors of $\mathrm{Hsp} 90$ prevent alpha-synuclein oligomer formation and rescue alpha-synuclein-induced toxicity. J Pharmacol Exp Ther 2010, 332:849-857.

173. Sharma N, Hewett J, Ozelius LJ, Ramesh V, McLean PJ, Breakefield XO, Hyman BT: A close association of torsinA and alpha-synuclein in Lewy bodies: a fluorescence resonance energy transfer study. Am J Pathol 2001, 159:339-344

174. Shin Y, Klucken J, Patterson C, Hyman BT, McLean PJ: The co-chaperone carboxyl terminus of Hsp70-interacting protein (CHIP) mediates alphasynuclein degradation decisions between proteasomal and lysosomal pathways. J Biol Chem 2005, 280:23727-23734

175. Tetzlaff JE, Putcha P, Outeiro TF, Ivanov A, Berezovska O, Hyman BT, McLean PJ: CHIP targets toxic alpha-Synuclein oligomers for degradation. J Biol Chem 2008, 283:17962-17968.

176. Parnetti L, Castrioto A, Chiasserini D, Persichetti E, Tambasco N, El-Agnaf O, Calabresi P: Cerebrospinal fluid biomarkers in Parkinson disease. Nat Rev Neurol 2013, 9:131-140.

doi:10.1186/1750-1326-9-43

Cite this article as: Moussaud et al.: Alpha-synuclein and tau: teammates in neurodegeneration? Molecular Neurodegeneration 2014 9:43. 